УДК 629.436

DOI 10.47049/2226-1893-2020-2-106-119

\title{
ПІДВИЩЕННЯ ПАЛИВНОЇ ЕКОНОМІЧНОСТІ СУДНОВИХ ДИЗЕЛЬНИХ УСТАНОВОК
}

Ю.В. Заблоцький

кандидат технічних наук, доцент

Національний університет «Одеська морська академія»

Анотація. Розглянути питання підвищення паливної економічності суднових дизельних установок иляхом використання присадок до палива. Наведені результати експериментальних досліджень, щзо виконувались на судновому середньообертовому дизелі 6N21L фірми Yаптаг, до витратної паливної цистерни якого додавалась паливна присадка з різною концентрацією. Встановлено, щзо за рахунок використання паливних присадок на різних режимах роботи суднового вказаного дизеля можливо досягти зниження питомої витрати палива від 2,6 до 4,8\%. При изьому максимальне підвищення паливної економічності відбувається в діапазоні 50-60\% навантаження дизеля, тобто режимів, щуо характеризуються найбільшим експлуатаційним періодом роботи, а також підвищеною тепловою напруженістю. Також виявлено, що використання присадок до палива сприяс зниженню на 3,3-7,2\% температури випускних газів та на 46,2-58,3 \% знижує неузгодженість значення температури випускних газів по окремих циліндрах дизеля.

Ключові слова: судновий середньообертовий дизель, присадки до палива, питома ефективна витрата палива, паливна економічність, температура випускних газів.

УДК 629.436

DOI 10.47049/2226-1893-2020-2-106-119

\section{ПОВЫШЕНИЕ ТОПЛИВНОЙ ЭКОНОМИЧНОСТИ СУДОВЫХ ДИЗЕЛЬНЫХ УСТАНОВОК}

Ю.В. Заблоцкий

кандидат технических наук, доцент

Национальный университет «Одесская морская академия»

Аннотация. Рассмотрень вопросы повышения топливной экономичности судовых дизельных установок путем использования присадок к топливу. Приведенные результать экспериментальных исследований, выполненные на судовом среднеоборотном дизеле 6N21L фирмы Yanтаr, в расходную топливной ичистерны которого добавлялась топливная присадка с разной конщентрациией.

(C) Заблоцький Ю.В., 2019 
Установлено, что за счет использования топливных присадок на различных режимах работь указанного судового дизеля возможно добиться снижения удельного расхода топлива от 2,6 до 4,8\%. При этом максимальное повышение топливной экономичности происходит в диапазоне 50-60\% нагрузки дизеля, то есть режимах, характеризующиххя наибольшим эксплуатационным периодом работы, а также повышенной тепловой напряженностью. Также выявлено, что использование присадок к топливу способствует снижению на 3,3-7,2 \% температуры выпускных газов и на 46,2-58,3\% снижает несогласованность значение температуры выпускных газов по отдельным ичилиндрам дизеля.

Ключевые слова: судовой среднеоборотный дизель, присадки к топливу, удельный эффективный расход топлива, топливная экономичность, температура выпускных газов.

\title{
UDC 629.436
}

DOI 10.47049/2226-1893-2020-2-106-119

\section{IMPROVING THE FUEL ECONOMY OF MARINE DIESEL ENGINES}

\author{
Yu. Zablotsky \\ Candidate of Technical Sciences, Associate Professor \\ National University «Odessa Maritime Academy»
}

\begin{abstract}
The questions of increasing the fuel efficiency of marine diesel engines by using fuel additives are considered. As a method of preparing fuel for use in a diesel engine, chemical treatment (the use of fuel additives) is proposed. Difficulties due to which the use of fuel additives in marine power engineering are not widely used are indicated. It is noted that the use of fuel additives is especially relevant for ship auxiliary engines, which ensure the operation of electric generators. These types of engines are characterized by an increased (compared to the main engines) crankshaft rotation speed, as well as continuous operation as part of a ship's power plant (both in running and in special modes of operation of the vessel). The first (increased frequency) reduces the fuel injection time, the second (work during parking in the seaport waters) imposes additional requirements for ensuring environmental performance of engines. It was determined that it is for these diesels that the use of fuel additives is the main way to increase fuel economy. The results of experimental studies that were performed on 6N21L marine medium speed diesels manufactured by Yanmar of a marine vessel with a deadweight of 51200 tons. The fuel systems of two diesel engines were additionally equipped with a flow meter and an additive dispenser, which ensured that the additive with different concentrations was added to the volume of fuel that enters the high pressure fuel pumps. It has been established that through the use of fuel
\end{abstract}


additives in various operating modes of the specified marine diesel it is possible to achieve a reduction in specific fuel consumption from 2,6 to 4,8\%. In this case, the maximum increase in fuel efficiency occurs in the range of $50-60 \%$ of the diesel load, that is, the modes characterized by the longest operating period of operation, as well as increased thermal tension. It was also revealed that the use of fuel additives helps to reduce the temperature of the exhaust gases by 3,3-7,2\% and by 46,2-58,3\% reduces the inconsistency of the temperature of the exhaust gases in individual diesel cylinders.

Keywords: marine medium-speed diesel, fuel additives, specific effective fuel consumption, fuel efficiency, exhaust gas temperature.

Постановка проблеми в загальному вигляді. Суднові дизельні установки відносяться до найпоширенішого типу енергетичних установок, які використовуються на морських і річкових суднах. Порівняно 3 паровими котлами та газовими турбінами суднові дизелі характеризуються мінімальними витратами палива як на одиницю потужності (кг/кВт·год), так і на одиницю пройденого судном шляху (кг/миля). Це $\epsilon$ головною причиною, через яку вони в найбільшій кількості (до 95-97 \% порівняно 3 іншими типами теплових двигунів) встановлюються як головні і допоміжні двигуни морських і річкових суден [1]. Отримання корисної роботи у будь-якому тепловому двигуні супроводжується витратами палива (рідкого або газоподібного), яке є джерелом енергії. За різними оцінками, витрати на паливо можуть досягати до $35-40$ \% від за-гальних витрат на обслуговування суднової енергетичної установки. Використання палива в судновій енергетиці неможливо без його попередньої обробки, при цьому забезпечується видалення з палива механічних домішок та води, а також підтримання необхідної в'язкості палива, за якої можливі його рух у системі та впорскування в циліндр дизеля [2].

Одним із методів підготовки палива до використання є його хімічна обробка, яка забезпечується за рахунок введення в нього паливних присадок. При цьому на відміну від найбільш розповсюджених способів обробки палива - фільтрації та сепарації (які використовуються у всіх без винятку системах підготовки палива), використання присадок до судно-вого палива, хоча на даний час й набуло досить широкого поширення на суднах, не завжди отримує однозначну оцінку. Це пов'язано $з$ різними причинами, які, перш за все, залежать від характеристик суднового дизеля й елементів його паливної системи, а також від забезпечення правильної технології використання присадок [3; 4].

Аналіз останніх досліджень i публікацій. Використання присадок до палива, як правило, вивчається для автомобільної техніки та стаціонарної енергетики [5]. Можливість запровадження такого методу 
підготовки палива, як його хімічна обробка (тобто використання присадок) у суднову енергетику обмежується автономністю роботи морських суден та неможливістю безперешкодно отримати необхідні присадки в портах, у яких здійснюється бункеровка. Відсутність окремих танків, заздалегідь призначених для збереження присадок до палива, змушує до їх перевезення в окремих ємностях, що не передбачено обмеженим простором машинного відділення. Усе це негативно впливає не лише на можливість використання присадок до палива, але й на можливість проведення експериментальних досліджень, які сприятимуть визначенню оптимальних режимів їхнього використання.

Використання паливних присадок особливо актуально для допоміжних двигунів, які є приводами електричних генераторів. Дані типи двигунів характеризує підвищена (порівняно 3 головними двигунами) частота обертання колінчастого валу, а також безперервна робота у складі суднової електростанції (як на ходових, так і на спеціальних режимах експлуатації судна). Перше (підвищена частота) скорочує час впорскування палива, друге (робота під час стоянок в акваторії морських портів) накладає додаткові вимоги щодо забезпечення екологічних показників роботи двигунів.

Постановка завдання. На даний момент конструктивне і технологічне виконання суднових дизелів досягло своєї досконалості, що забезпечує мінімальні енергетичні втрати та питомі витрати палива даних типів теплових двигунів порівняно 3 іншими (паровими котлами та газовими турбінами) [6; 7]. Тому використання присадок до палива вважається одним із шляхів підвищення паливної економічності дизелів. У зв'язку 3 цим метою дослідження було визначення впливу паливних присадок на економічність та експлуатаційні показники роботи суднового дизеля.

Виклад основного матеріалу дослідження. Дослідження в умовах морського судна дедвейтом 51200 тонн були виконані на судновому дизелі 6N21L фірми Yanmar 3 наступними основними характеристиками: тип - рядний 3 водяним охолодженням; 4-тактний, 3 газотурбінним наддувом; діаметр циліндра - 0,21 м; хід поршня - 0,29 м; частота обертання - $720 \mathrm{xв}^{-1}$ (об/хв); кількість циліндрів - 6; номінальна потужність 680 кВт.

До складу суднової енергетичної установки входило три названих дизелі, що використовуються в якості дизель-генераторів. Це дозволило два дизелі використовувати для проведення експериментів, а один залишати в якості «контрольного». Схема паливної системи дизелів наведена на рис. 1. Паливна система «контрольного» дизеля (КД) не зазнала модернізації. Паливна система «експериментальних» дизелів (ЕД) дообладнати витратоміром 6 і дозатором присадки 7. Така організація подачі присадки до паливної системи забезпечувала необхідну дисперсію і рівно-мірний рівень іiі розчинення в паливі. 

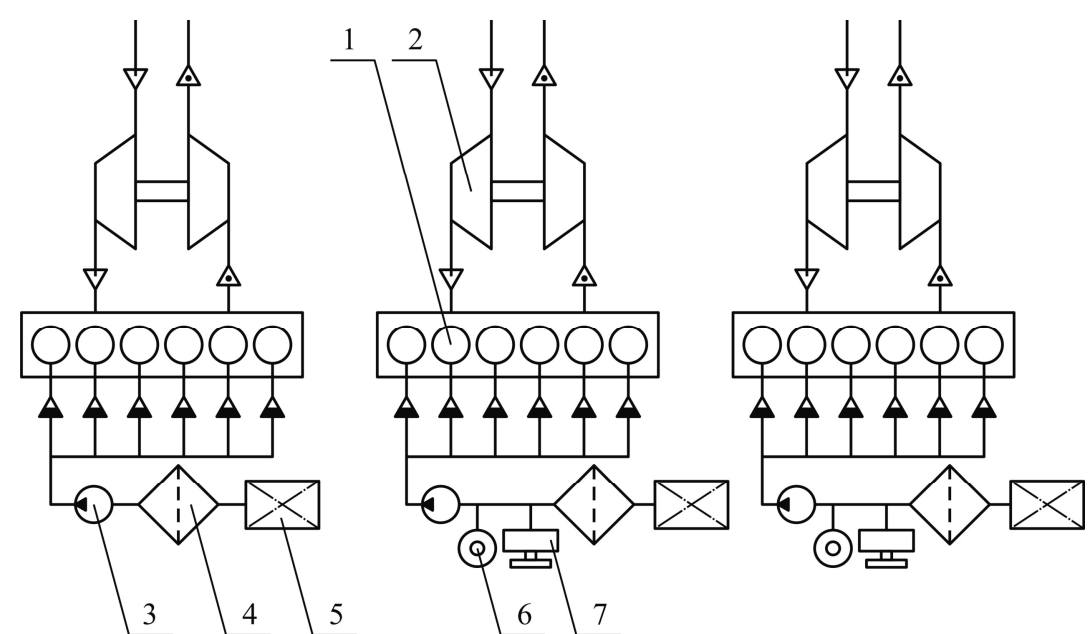

Рис. 1. Паливна система суднового дизеля $6 \mathrm{~N} 21 \mathrm{~L}$

фірми Yаптаг (фрагмент):

1 - дизель; 2 - газотурбокомпресор; 3 - насос, що підкачує паливо;

4 - паливний фільтр тонкого очищення; 5 - витратна цистерна; 6-витратомір; 7 - дозатор присадки

Під час проведення експерименту концентрація присадки в паливі обиралась 3 рекомендованого фірмою-виробником діапазону та приймалася рівною 1:2000, 1:4000, 1:6000, 1:8000 до загального обсягу палива, що знаходилось у витратній цистерні.

Режими роботи суднової електростанції характеризуються різноманітністю зміни навантаження [8], значення якої для даної суднової енергетичної установки коливалися в діапазоні від 180-200 кВт (коли в експлуатації знаходився один 3 дизелів) до 1500-1600 кВт (коли експлуатувалися три дизелі, що працюють в паралельному режимі).

У разі, коли дизелі працювали в паралельному режимі з будь-якої зі схем підключення: КД-ЕД, КД-ЕД-ЕД, ЕД-ЕД, навантаження на кожен 3 них становило $N_{\mathrm{e}}=300-600$ кВт і підтримувалося на однаковому рівні 3 відхиленням \pm 10 кВт.

Потужність дизелів $N_{\mathrm{e}}$ визначалася за виразом $N_{e}=N_{\mathrm{g}} / \eta_{\mathrm{g}}$ (де $N_{g}-$ потужність генератора, кВт, $\eta_{\mathrm{g}}-$ коефіцієнт корисної дії генератора). Значення $N_{g}$ знімалося з ватметра, розташованого на панелі керування дизель-генератора, а величина $\eta_{\mathrm{g}}$ приймалася з паспортних характеристик дизель-генератора i становила $\eta_{\mathrm{g}}=0,915$. Для розрахунку величини питомої ефективної витрати палива $b_{e}$ за вимірником рівня (розташованим на кожній витратній цистерні) визначалася поточна витрата палива $G_{\text {п }}$ та величина питомої ефективної витрати палива $b_{e}$.

Для забезпечення ідентичності експерименту для всіх дизелів проводилася їх попередня підготовка до випробувань. Умови експлуатації 
дозволяли послідовно протягом 40 годин виконати повну моточистку зазначених дизелів, тим самим підготувати їх до експерименту. При цьому на всіх дизелях замінювалася поршнева група (поршні і поршневі кільця) і основні елементи паливної системи високого тиску (прецизійних пар паливного насоса високого тиску плунжер - гільза та голка розпилювач форсунки). Крім того, перед початком експериментів для обох двигунів проводився контроль і регулювання паливної апаратури. При цьому паливні насоси високого тиску регулювалися на однаковий кут випередження подачі палива, а форсунки двигунів налаштовувалися на однакові тиски підйому голки. Протягом усього часу проведення експерименту здійснювався контроль часу роботи та експлуатаційного навантаження на дизелі. Для досягнення рівномірного розподілу часу роботи дизелів двигуни послідовно переводилися в режим stand-by. Шляхом перепідклю-чення споживачів енергії неузгодженість потужності дизель-генераторів, на яких відбувалися дослідження, не перевищувало 10 кВт, що для таких енергоємних об'єктів можна вважати незначним відхиленням, а умови їх роботи ідентичними. Експлуатація двигунів проводилася на одному й тому ж сорті палива. При цьому засоби автоматичного контролю підтримували в'язкість палива незмінною протягом усього експерименту. Ідентичним підтримувався сорт циркуляційного мастила, що забезпечує режими змащування, і його експлуатаційні характеристики, а також температури в контурі охолодження прісною водою. Дані заходи дозволили вважати, що виконання експерименту проводилося в однакових умовах.

Визначення впливу паливних присадок на теплову напруженість деталей суднового дизеля. Як критерій теплової напруженості газовипускної системи приймалися температури випускних газів перед газотурбонагнітачем. Крім того, у процесі експерименту визначалася питома ефективна витрата палива [3; 8].

Температура газів на виході 3 циліндра двигуна $€$ однією 3 характеристик, що визначають як якість перебігу робочого циклу, так i ступінь теплової напруженості деталей дизеля [9]. Найбільш часто іiі вимірюють у випускній магістралі перед газотурбонагнітачем. На рис. 2 показані залежності усередненої за всіма циліндрами температури газів на

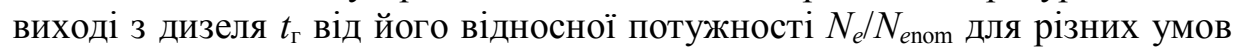
ïx експлуатації (тільки на паливі і на паливі з різною концентрацією присадки).

Як видно 3 рис. 2, використання присадок до палива сприяє зниженню температури газів на виході 3 дизеля, що свідчить про більш повне згоряння палива і максимальне використання теплової енергії газів безпосередньо в циліндрі. При цьому мінімальну температуру випускних газів $t_{\mathrm{r}}^{\mathrm{min}}=383{ }^{\circ} \mathrm{C}$ забезпечувало використання палива 3 концентрацією при-садки 1:6000. 
ВІСНИК

ОДЕСЬКОГО НАЦІОНАЛЬНОГО МОРСЬКОГО УНІВЕРСИТЕТУ № 2 (62), 2020
HERALD

OF THE ODESSA NATIONAL

MARITIME UNIVERSITY № 2 (62), 2020

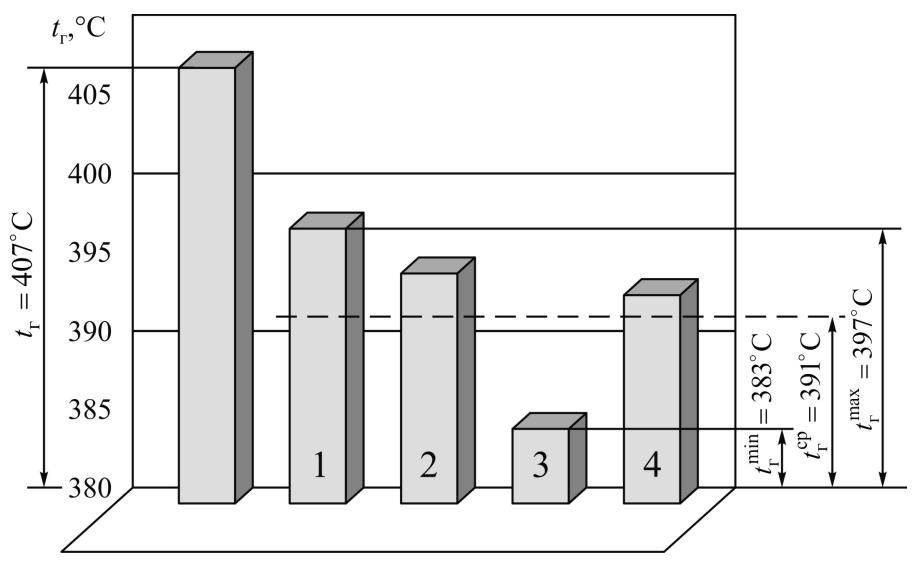

Рис. 2. Залежності середньої температури відхідних газів $t_{2}$ за циліндрами дизеля 6N21L для «контрольного» дизеля

$i$ «експериментальних» дизелів, що праџюють на паливі з концентрацією присадки:

$1-1: 2000,2-1: 4000,3-1: 6000,4-1: 8000$

При концентрації присадки в паливі 1:2000 спостерігалася максимальна (для «експериментальних» дизелів) температура випускних газів $t_{\Gamma}^{\max }=397{ }^{\circ} \mathrm{C}$, однак ії величина була менше температури $t_{\Gamma}=407{ }^{\circ} \mathrm{C}$ на «контрольному» дизелі. Середнє значення при використанні палива 3 різною концентрацією присадки становило $t_{\mathrm{r}}^{\mathrm{cep}}=391{ }^{\circ} \mathrm{C}$. Наведені результати були отримані при ефективній потужності дизеля 530 кВт, що у відносних величинах складало $N_{e} / N_{e n o m}=78 \%$.

Для суднових дизелів при оцінці рівня теплової напруженості важливим також $є$ ступінь неузгодженості температури випускних газів по окремих циліндрах. Результати, що були отримані при випробуваннях, наведені на рис. 3.

Відхилення температури випускних газів одного з циліндрів від середнього значення по всіх циліндрах дизеля може свідчити про неправильне регулювання або погіршення технічного стану паливної апаратури високого тиску. Ще однією причиною підвищеної неузгодженості температури випускних газів по циліндрах дизеля може бути погіршення процесу сумішоутворення i згоряння палива. Під час проведення експериментів було визначено менше відхилення температури випускних газів по циліндрах дизеля від його усередненого значення при використанні присадки до палива. Для «контрольного» дизеля (зі значенням відносної потужності дизеля $N_{e} / N_{\text {enom }}=78 \%$ ) при величині $t_{\text {cер }}^{\Gamma}=407{ }^{\circ} \mathrm{C}$ цей параметр склав $\Delta t_{\text {cep }}^{-}=12{ }^{\circ} \mathrm{C}, \Delta t_{\text {cep }}^{+}=13{ }^{\circ} \mathrm{C}$. 


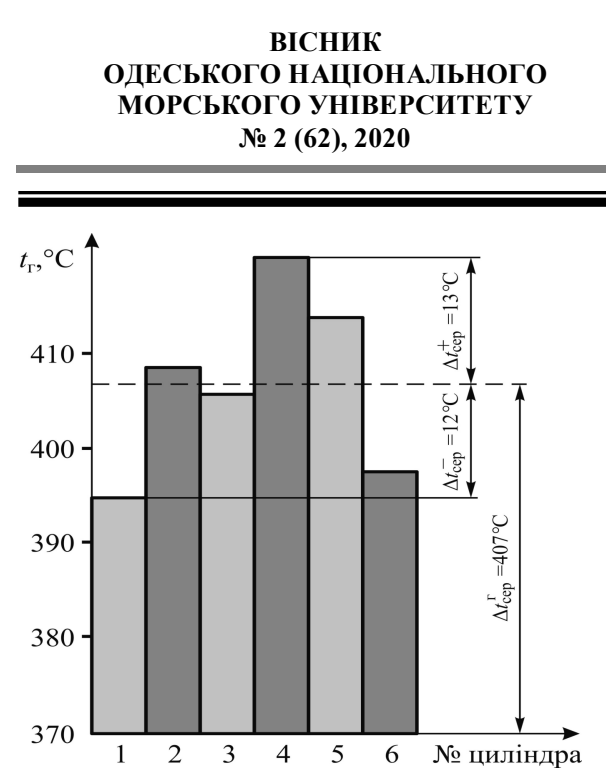

a)

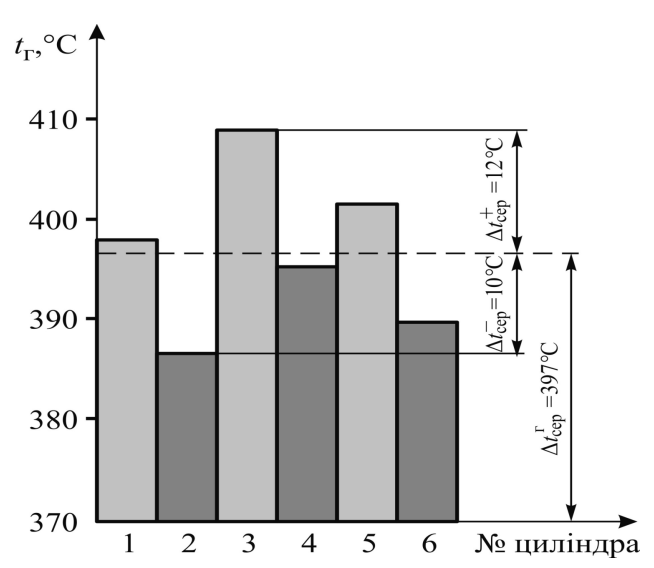

б)

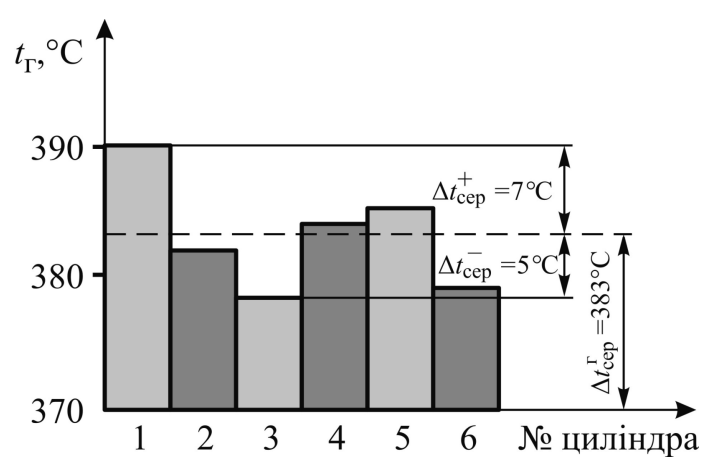

в)

Рис. 3. Неузгодженість температури випускних газів $t_{2}$ по ииліндрах дизеля 6N21L за різних умов проведення експерименту:

а) робота дизеля без використання паливної присадки;

б), в) робота дизеля з використанням паливної присадки з конщентрацією 1:2000 і 1:6000 відповідно

Для «експериментального» дизеля при використанні палива 3 концентрацією присадки $1: 2000$ iз середнім значенням температури випускних газів $t_{\text {сер }}^{\mathrm{r}}=397{ }^{\circ} \mathrm{C}$ відхилення склали $\Delta t_{\text {cep }}^{-}=10{ }^{\circ} \mathrm{C}, \Delta t_{\text {cep }}^{+}=12$ ${ }^{\circ} \mathrm{C}$. Для дизеля при використанні палива 3 концентрацією присадки 1:6000 iз середнім значенням температури випускних газів $t_{\text {cep }}^{\text {厂 }}=383{ }^{\circ} \mathrm{C}$ відхилення склали $\Delta t_{\text {cep }}^{-}=5^{\circ} \mathrm{C}, \Delta t_{\text {сер }}^{+}=7^{\circ} \mathrm{C}$ (див. рис. 3). 
Подальші дослідження виконувалися на паливі з концентрацією присадки 1:2000 i 1:6000. Які, як було показано вище, забезпечували максимальну і мінімальну теплову напруженість в елементах газовипускної системи. При цьому режими проведення досліджень варіювалися в межах 52-88\% від номінальної потужності. Отримані при цьому результати показані на рис. 4.

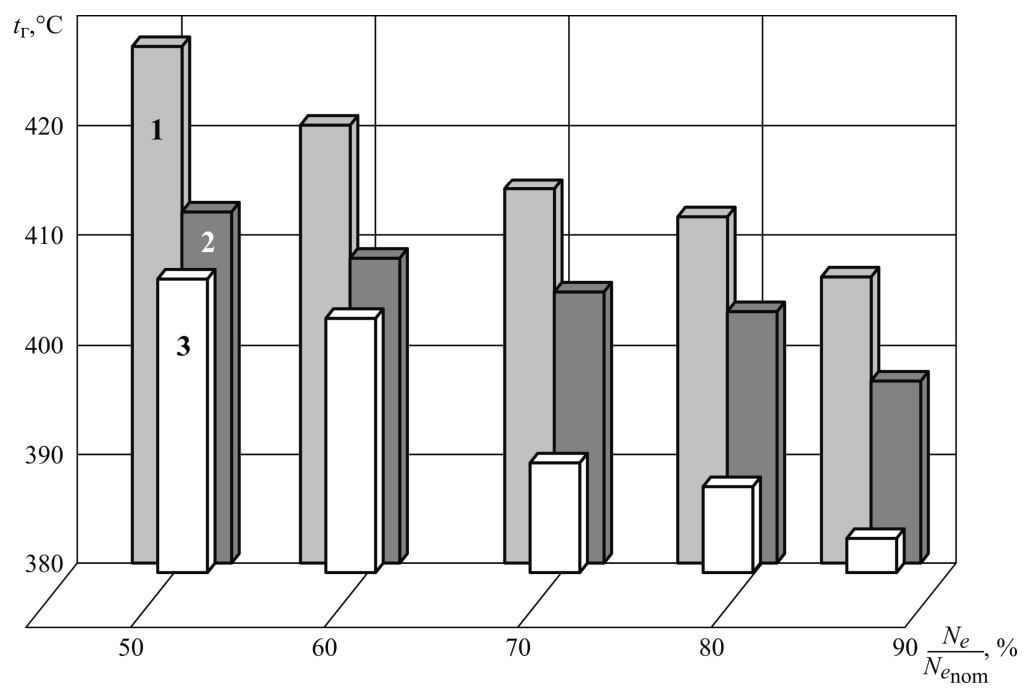

Рис. 4. Залежність температури випускних газів $t_{2}$ по ииліндрах суднового дизеля $6 N 21 L$ від його відносної потужності $N_{e} / N_{\text {епот }}$ :

1 - «контрольний» дизель (без використання паливної присадки);

2, 3 - «експериментальні» дизелі (при використанні паливної присадки з концентрацією 1:2000 і 1:6000 відповідно)

Наведені дані свідчать про принципове зниження теплової напруженості (температури випускних газів) під час використання палива 3 присадкою. Діапазон зниження середньої температури випускних газів становить 4,1-8,2 \% залежно від режиму роботи дизеля.

Визначення впливу паливних присадок на економічність роботи дизеля. Паралельно 3 визначенням впливу паливних присадок на теплову напруженість газовипускної системи виконалися дослідження їх впливу на економічність роботи дизеля. При цьому в якості критерію приймалася питома ефективна витрата палива $b_{\mathrm{e}}$, значення якого у г/(кВТ·год). Було встановлено, що використання палива 3 присадкою сприяє зниженню даного показника у всьому діапазоні експлуатаційних навантажень (рис. 5). 


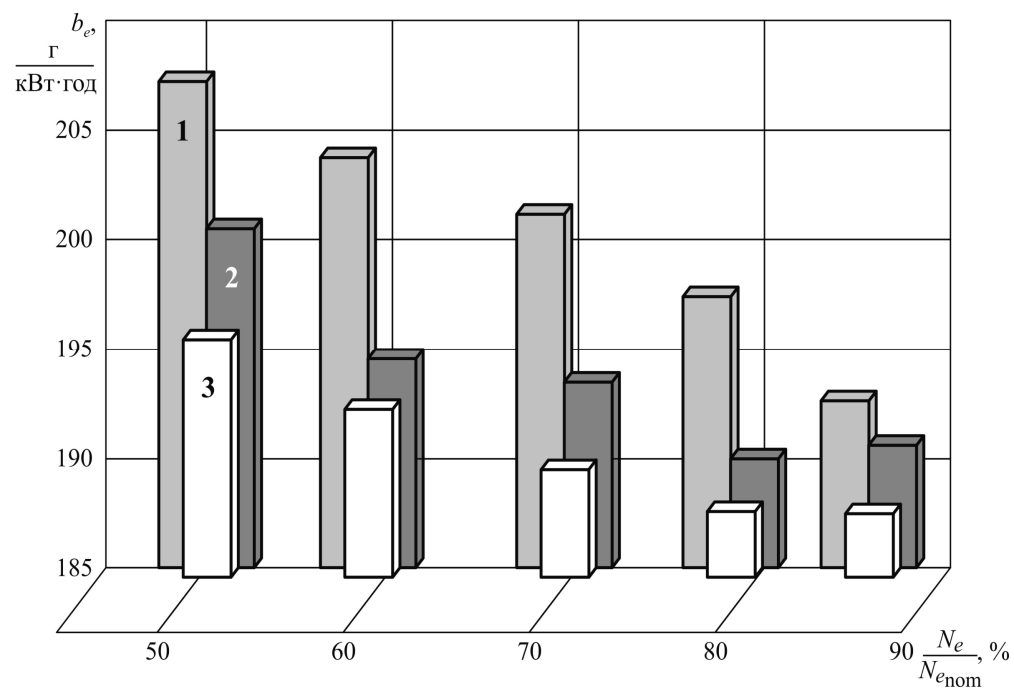

Рис. 5. Зміна питомої ефективної витрати палива $b_{e}$ суднового дизеля $6 N 21 L$ при різних значеннях його відносної потужності $N_{e} / N_{\text {епот: }}$ : 1 - «контрольний» дизель (без використання паливної присадки);

2, 3 - «експериментальні» дизелі (при використанні паливної присадки з концентрацією 1:2000 і 1:6000 відповідно)

Експериментально отримані результати, що підтверджують зниження питомої ефективної витрати палива із використанням паливних присадок, свідчать про інтенсифікацію процесу сумішоутворення i згоряння палива. Це призводить до більш повного використання його теплотворної здатності та зниження кількості палива, що догоряє на ході розширення і у випускному колекторі. При цьому відзначимо, що для різної концентрації присадки в базовому паливі спостерігається різна величина зниження питомої ефективної витрати палива. На наш погляд, це пояснюється тим, що частина вільних радикалів присадки залишається незадіяною в розриві внутрішньо молекулярних зв'язків палива й активації його горючих складових.

Наслідком поліпшення процесу згоряння палива і зміщення його протікання на лінію ізохорного підведення тепла також є зниження температури випускних газів. Це пов'язано 3 тим, що застосування присадок до палива сприяє перебігу процесу згоряння в циліндрі дизеля не лінією розвитку ланцюгової реакції, що веде до детонації, а лінією розвитку стаціонарного горіння.

Наведені результати свідчать про більш якісне сумішоутворення $\mathrm{i}$ згоряння, а також більш повне використанні теплотворної здатності палива з присадкою. 
Висновки і перспективи подальших досліджень. Таким чином, наведені результати дозволяють зробити наступні висновки.

1. Одним із методів покращення експлуатаційних властивостей палива $\epsilon$ використання паливних присадок, які можуть вводитися до паливної системи в різних точках: відстійному танку, витратному танку, паливних магістралях, а також перед його безпосередньою подачею в циліндр дизеля (перед паливним насосом високого тиску).

2. Експериментально отримані результати, що підтверджують зниження питомої ефективної витрати палива під час використання паливних присадок, свідчать про інтенсифікацію процесу сумішоутворення і згоряння палива. Це призводить до більш повного використання його теплотворної здатності та зниження кількості палива, що догоряє на ході розширення та у випускному колекторі. При цьому відзначимо, що для різної концентрації присадки в базовому паливі спостерігається різна величина зниження питомої ефективної витрати палива. На наш погляд, це пояснюється тим, що частина вільних радикалів присадки залишається незадіяною в розриві внутрішньо молекулярних зв'язків палива й активації його горючих складових. Експериментально підтверджено, що під час використання паливних присадок на різних режимах роботи суднового чотиритактного дизеля можливо досягти зниження питомої витрати палива від 2,6 до 4,8 \%. При цьому максимальне підвищення паливної економічності відбувається в діапазоні 50-60\% навантаження дизеля, тобто режимів, що характеризуються найбільшим експлуатаційним періодом роботи, а також підвищеною тепловою напруженістю.

3. Використання паливних присадок не тільки знижує загальні витрати палива, але й сприяє зниженню температури випускних газів на 3,3-7,2 \% і зменшує іiі відхилення по циліндрах дизеля, вирівнюючи таким чином теплове навантаження по окремих циліндрах. Під час використання присадок до палива на 46,2-58,3 \% знижується неузгодженість значення температури випускних газів по окремих циліндрах від іiі середнього значення. Це забезпечує вирівнювання теплового навантаження по всіх циліндрах дизеля і також зменшує теплову напруженість, що виникає в ньому.

4. Концентрація присадки має оптимальне значення, визначається експериментально і залежить від характеристик дизеля і використовуваного палива. Визначення оптимальної концентрації можливе безпосередньо на судновому дизелі відповідно до розроблених технологічних схем та з використанням запропонованих рекомендацій. 


\section{СПИСОК ЛІТЕРАТУРИ}

1. Kuropyatnyk, O. A. Exhaust Gas Recirculation as a Major Technique Designed to Reduce NOx Emissions from Marine Diesel Engines / O.A. Kuropyatnyk, S.V. Sagin // OUR SEA: International Journal of Maritime Science \& Technology, 2019. Vol. 66. Iss. 1. P. 1-9.

2. Сагин С.В. Применение ультразвуковой обработки топлива для снижения сернистого износа двигателя / С.В. Сагин, В.Г. Солодовников // Технические науки - от теории к практике. Сб. ст. по материалам ХХХV междунар. науч.-практ. конф. № 6 (31). Новосибирск: «СибАК》, 2014. С.42-48.

3. Zablotsky, Yu. V. Enhancing Fuel Efficiency and Environmental Specifications of a Marine Diesel When using Fuel Additives / Yu. V. Zablotsky, S. V. Sagin // Indian Journal of Science and Technology, Published by Indian Society of Education and Environment. December 2016. Vol. 9. Iss. 46. P. 353-362. DOI: $10.17485 / i j s t / 2016 / v 9 i 46 / 107516$.

4. Сагин С.В. Использование топливных присадок в судовых дизелях / С.В. Сагин, Ю.В. Заблочкий // Судовые энергетические установки: науч.-техн. сб., 2012. № 30. Одесса: ОНМА. C.180-186.

5. Спиркин В.Г. Экологические проблемы применения топлив с присадками / В.Г. Спиркин, И.И. Ткачев, П.А. Татарышкина // Вестник национального авиационного университета, 2009. T. 1. № 38. C. 68-79.

6. Сагин С.В. Определение триботехнических характеристик поверхностей по степени упорядоченности пристенных слоев углеводородных жидкостей / С.В. Сагин, Ю.В. Заблочкий // Проблеми техніки: наук.-виробн. журнал, 2011. № 3. Одесса: ОНМУ. С. 78-88.

7. Поповский А.Ю. Комплексная оценка эксплуатационных характеристик смазочных углеводородных жидкостей / А.Ю. Поповский, С.В. Сагин // Автоматизация судовых технических средств: науч.-техн. сборник. 2014. Bып. 20. C. 74-83.

8. Заблочкий Ю.В. Повышение топливной экономичности и экологических параметров работы судовых дизелей при использовании присадок к топливу / Ю.В. Заблоикий, А.А. Куропятник // Austria-science, 2017. № 2. C. 83-88. 
9. Куропятник А.А. Управление выпускными газами судовых дизелей для обеспечения экологических показателей / A.А. Куропятник, С.В. Сагин // Автоматизация судовых технических средств: науч.-техн. сборник, 2018. Bып. 24. C. 72-80.

\section{REFERENCES}

1. Kuropyatnyk, O.A., Sagin, S.V. (2019) Exhaust Gas Recirculation as a Major Technique Designed to Reduce NOx Emissions from Marine Diesel Engines. OUR SEA: International Journal of Maritime Science \& Technology, vol.66, no. 1, pp. 1-9. doi.org/10.17818/NM/2019/1.1.

2. Sagin, S.V., Solodovnikov, V.G. (2014) Primenenie ultrazvukovoj obrabotki topliva dlya snizheniya sernistogo iznosa dvigatelya [The use of ultrasonic fuel treatment to reduce engine sulfur wear]. Materials of the XXXV international scientific-practical conference "Technical science - from theory to practice», Novosibirsk: SibAK, no. 6(31), pp. 42-48.

3. Zablotsky, Yu.V., Sagin, S.V. (2016) Enhancing Fuel Efficiency and Environmental Specifications of a Marine Diesel When using Fuel Additives. Indian Journal of Science and Technology, vol. 9, no. 46, pp. 353-362. DOI: 10.17485/ijst/2016/v9i46/107516.

4. Sagin, S.V., Zablotsky, Yu.V. (2012) Ispolzovanie toplivnyh prisadok $v$ sudovyh dizelyah [Use of fuel additives in marine diesel engines]. Sudovye energeticheskie ustanovki : nauchnotehnicheskij sbornik, no. 30, pp. 180-186.

5. Spirkin V.G., Tkachev I.I., Tataryshkina P.A. (2009) Ekologicheskie problemy primeneniya topliv s prisadkami [Environmental problems of the use of fuels with additives]. Vestnik nacionalnogo aviacionnogo universiteta, vol. 1, no. 38, pp. 68-79. (in Russian)

6. Sagin, S.V., Zablotsky, Yu.V. (2011) Opredelenie tribotehnicheskih harakteristik poverhnostej po stepeni uporyadochennosti pristennyh sloev uglevodorodnyh zhidkostej [Determination of tribological characteristics of surfaces according to the degree of ordering of wall layers of hydrocarbon fluids]. Problemy texniky: naukovo-vyrobnychj zhurnal, no. 3, pp. 78-88.

7. Popovskii, A.Yu., Sagin, S.V. (2014) Kompleksnaya ocenka ekspluatacionnyh harakteristik smazochnyh uglevodorodnyh zhidkostej [Comprehensive performance assessment of lubricating hydrocarbon fluids]. Avtomatizaciya sudovyh tehnicheskih sredstv: nauchno-tehnicheskij sbornik, no. 20, pp. 74-83. 
ВІСНИК

ОДЕСЬКОГО НАЦІОНАЛЬНОГО

МОРСЬКОГО УНІВЕРСИТЕТУ

№ 2 (62), 2020
HERALD

OF THE ODESSA NATIONAL

MARITIME UNIVERSITY

№ 2 (62), 2020

8. Zablotsky, Yu.V., Kuropyatnyk, O.A. (2017) Povyshenie toplivnoj ekonomichnosti $i$ ekologicheskih parametrov raboty sudovyh dizelej pri ispolzovanii prisadok $k$ toplivu [Improving fuel economy and environmental performance of marine diesel engines using fuel additives]. Austria-science, no. 2, pp. 83-88.

9. Kuropyatnyk, O.A., Sagin, S.V. (2018) Upravlenie vypusknymi gazami sudovyh dizelej dlya obespecheniya ekologicheskih pokazatelej [Controlling the exhaust gases of marine diesel engines to ensure environmental performance]. Avtomatizaciya sudovyh tehnicheskih sredstv: nauchno-tehnicheskij sbornik, no.24, pp. 72-80.

Стаття надійшла до редакиії 25.03.2020

Посилання на статтю: Заблоцький Ю.В. Підвищення паливної економічності суднових дизельних установок // Вісник Одеського національного морського університету: 3б. наук. праць, 2020. № 2(62). С. 106-119. DOI 10.47049/2226-1893-2020-2-106-119.

Article received 25.03.2020

Reference a JournalArtic: Zablotsky, Yu. Improving the fuel economy of marine diesel engines // Herald of the Odessa national maritime university. 2020. 2(62), 106-119. DOI 10.47049/2226-1893-2020-2-106-119. 